\title{
MOBILE LEARNING GAMES FOR DYSLEXIC YOUNG ADULTS
}

\author{
Sarmīte Tūbele \\ University of Latvia, Latvia
}

\begin{abstract}
This article is devoted to revealing the theoretical background of dyslexia in young adults to substantiate the chosen approach for mobile learning games. Education in the 21st century has changed just the same as young adult learners; especially those who have some developmental problems, such as developmental dyslexia. If they are lucky to encounter smart teachers, understanding parents, siblings and peers, they succeed in the education system, they reach learning goals and are satisfied with their life quality. If there are gaps between regulations, rules and the real situation, learners lose interest in learning and especially in reading, they do not achieve their learning goals and sometimes they even experience school failure. Educators have to think about new methods, new approaches to diminish the possibilities of failure, to renew interest in learning (and especially in reading) to achieve education goals and to ensure the possibility for better life quality. The article deals with theoretical findings in differences of dyslexia in young adults and the role of technologies and educational mobile games in the learning process.
\end{abstract}

Keywords: mobile learning games, dyslexia, young adults.

\section{Introduction}

Young adults with dyslexia are a group of learners who are not the main target group for new methods and approaches of learning. The manifestations of dyslexia in adults and young adults differ from those in children. The situation in pedagogy is developing and changing not by years but by days and technologies are in use everywhere. Erasmus + project "Learning Games for Dyslexic Young Adults" (2018-1-LV01KA204-046970) (DYS2GO) started with the idea to develop learning games on mobile devices especially for young adults with dyslexia who are disappointed in learning, without interest of learning and maybe even have experienced failure in school. Six European countries participate in this project: Austria, Czech Republic, Germany, Latvia, Lithuania and Romania (www.dys2go.eu). Theoretical background was needed to create mobile 
games, to meet the needs of young adults, and to understand their dyslexic essence.

The main aim of the article is to substantiate and create theoretical background for the needs of the project (to choose and create mobile learning games for dyslexic young adults).

Methods: review of scientific literature (Web of science and Google scholar were used) by searching key words: dyslexia, young adults, mobile learning games; as well as content analysis to define the categories for the research.

\section{Theoretical Framework and Findings in Scientific Literature}

The first task was to define the age group - young adults. Several authors (Ricketts, Lervag, Dawson, Taylor, \& Hulme, 2019) consider early adolescence to be at the age 12-14; some speak about early adolescence at the age 8-13 (Snowling, Muter, \& Carroll, 2007), while others define the age group of young adults as 16-25 (Nielsen et al., 2016). Taking into account the target group and main difficulties - our concept - the age group starts from 16. This is a very complicated age in general (Giles, 2005a; 2005b); sometimes there are identity formation problems (Giles, 2005b); sometimes - unique mental health crisis (Giles, 2005a); and especially for those who have dyslexia (Gibby-Leversuch, Hartwell \& Wright, 2019; Eden et al., 2004). Some of these individuals have had a really good support system in school during the first years of education. This means good support in the learning process, as well as an understanding attitude from peers, teachers and family. There are cases analysed in articles and research papers, where the attitude is not as supportive even in the family (Gibby-Leversuch et al., 2019). Then the educational system, particularly learning to read, sometimes presents problems; for some children it is real struggle (Gaskins, 2005); it is reinforced if they lose interest in reading (Tubele, 2010); and it happens if the process of reading is not successful. This means that the school's educational system has employed unsuccessful learning methods, the teachers have been unable to create and maintain an interest in reading, and the family has not been supportive enough. These learners risk losing interest in education altogether.

Dyslexia and developmental dyslexia. Developmental dyslexia is a specific learning (reading) disorder characterized by problems with coping with written symbols despite normal intelligence (Davis, n. d.; Snowling, 2015; Thompson et al., 2015). Not only do problems occur in the reading process, everyday life quality is also affected (Cho, Capin, Roberts, Roberts G., J., \& Vaughn, 2019). Dyslexic children and adults may have problems putting 
things in order, following instructions, may confuse left and right, and other manifestations. Each dyslexic person's difficulties are different and vary from light to very severe disruption of the learning process (Turkington, \& Harris, 2006). If they do not receive proper support during the learning process, they lose their motivation to learn and do not develop a positive attitude towards the learning process; this is especially influenced by the presence of both dyslexia and other learning disabilities.

Dyslexic young adults. Although difficulty in reading is a hallmark of dyslexia, particularly in children, most adults with dyslexia can read and have devised strategies to work around their reading difficulties: adults with dyslexia may also present a range of other characteristics, such as memory problems (Eden et al., 2004; Engelhardt, 2020; Hudson, High, \& Otaiba, 2007; Nielsen, et al., 2016). People with dyslexia do not, however, have trouble with vocabulary or speaking (Ricketts, et al., 2019). Young adults with dyslexia are a particular group that already exhibits insufficient interest in learning and reading. Strategies that would renew the joy of learning are required.

School failure. The causes of school failure include language disorder (oral or listening), reading disorder, mathematics disorder, writing disorder, and other problems, or a combination of some. The consequences of school failure result in remarkable economic loss to the nation, low self-esteem (Gibby-Levensuch, et al., 2019), sometimes even criminal behaviour. There is no research in Latvia about the consequences of school failure of dyslexic persons. Some authors present the results of studies about the healthrelated quality of life for children and adolescents with specific language impairments, which correlate with bad reading skills (Huber-Dibon, Bru, Gras Le Guen, Launay, \& Roy, 2016).

Reading interest is one of the pre-requisites of successful reading (Tubele, 2010). The era of digital literacy raises the question of whether the meaning of reading interest may be changed. There has been a case study about reading for 11-13 year-old students in the digital age (Fletcher, \& Nicholas, 2016) that draws interesting conclusions: there is a changing use of information communication technologies to engage and motivate young adolescents in reading; the use of iPads and laptops during reading facilitated interest in reading; assistive technology helps people with dyslexia save time and overcome challenges. This means that young adults with dyslexia need to renew their interest not only in reading, but the learning process as a whole, so the process would be pleasant and create joy and positive experiences; in this way, mobile games would create the impression of a pleasant process without connecting it with learning.

Technologies and Mobile learning. Due to the new era in the education where technologies become more and more important, there are many 
suggestions to use assistive technologies and mobile devices in the learning process, and especially for dyslexic learners: use technology to support reading and learning; use technology to support note taking, to support spelling and writing (Franceschini et al., 2019; Lavin-Mera, Torrente, MorenoGer, Vallejo-Pinto, \& Fernandez-Manjon, 2009; Pechenkina, Laurence, Oates, Eldridge, \& Hunter, 2017; Stiller, \& Schworm, 2019). A good way to learn more while having fun is to use games. Game/mobile learning is one of the possibilities to restore the interest in the learning process and in reading specifically (Wardaszko, \& Podgorski, 2017; Camilleri, \& Camilleri, 2019). Mobile learning is an innovative tool in education (Jinot, 2019), it gives an opportunity to reduce the cognitive load and enable learners to focus their resources on meaningful learning (Stiller, \& Schworn, 2019). Mobile learning is more effective (Pechenkina et al., 2017), and educational gaming gives an opportunity to broaden different approaches in teaching and learning (Lavin-Mera et al., 2009; Francechini et al., 2013). There are many Internet resources with fun dyslexia games for kids, students and adults; popular dyslexia games and websites; games from DyslexiaGames. com; three dyslexia programs for adults; multi-sensory programs; computer applications, and many other resources.

The created mobile games will be available for all who find them interesting, but they will carry the most importance for those young adults who have lost their interest in reading, who have experienced school failure. The games have been created so that the learning process and the improvement of reading skills would happen in a way that is pleasant and acceptable for young adults.

DYS2GO games. Games of the project DYS2GO are based on theoretical research about weak areas to be developed in dyslexic young adults. These areas are auditory perception, memory, discrimination, and sequence (Adlard, \& Hazan, 1998; Thompson et al., 2015; Engelhardt, 2020; Al Dahhan, Kirby, \& Munoz, 2016; McArthur, \& Castles, 2017; Hudson et al., 2007; Ramus, Marshall, Rosen, \& Van Der Lely, 2013), visual perception, memory, discrimination, and sequence (Kossowski, Chyl, Kacprzak, Bogorodzki, \& Jednorog, 2019; Viser, Boden, \& Giachi, 2004; Facoetti, Paganoni, Turatto, Marzola, \& Masetti, 2000; Facoetti et al., 2009), and spatial perception (Facoetti, n.d.; Facoetti et al., 2000; Facoetti et al., 2009; Kossowski et al., 2019). It was decided to create storylines that fit the interests of young boys and girls, to keep the fun of the game, and to develop reading skills. The player can choose either to read or to listen to the task. In accordance with the theoretical findings, different storylines (travelling, shopping, leisure time, adventure (archaeologist) and Jenny's story) were created. The next research will be devoted to test the games on young adults. 


\section{Conclusions}

- Young adults are a specific group of learners with different background.

- Dyslexic young adults sometimes have low self-esteem, they have lost interest in learning and especially in reading; school failure is possible.

- Reading interest is hard to create, easier to maintain, but there are possibilities to restore it by new approaches in education and the learning process.

- The use of technologies is a feature of the 21st century and mobile learning, educational games, and assistive technologies are crucial in the learning process of dyslexic individuals.

- Mobile learning games provide a perfect possibility to improve reading skills in dyslexic young adults and to promote better life quality.

\section{References}

Adlard, A., \& Hazan, V. (1998). Speech Perception in Children With Specific Reading Difficulties (Dyslexia). The Quarterly Journal of Experimental Psychology, 51A(1), 153177. doi: 10.1080/713755750.

Al Dahhan, N. Z., Kirby, J. R., \& Munoz, D. P. (2016). Understanding Reading and Reading Difficulties Through Naming Speed Tasks: Bridging the Gaps Among Neuroscience, Cognition, and Education. AERA Open. doi:10.1177/2332858416675346.

Camilleri, A. C., \& Camilleri, M. A. (2019). Mobile Learning via Educational Apps: An Interpretative Study. In Shun-Wing, N. G., Fun, T. S., \& Shi, Y. (Eds.) 5th International Conference on Education and Training Technologies (ICETT 2019). Seoul, SouthKorea (May, 2019). International Economics Development and Research Center (IEDRC). doi: 10.1145/3337682.3337687.

Cho, E., Capin, P., Roberts, G., Roberts, G. J., \& Vaughn, S. (2019). Examining Sources and Mechanisms of Reading Comprehension Difficulties: Comparing English Learners and Non-English Learners Within the Simple View of Reading. HHS Public Access. doi:10.1037/edu0000332.

Davis, R. D. (n.d.) The gift of dyslexia: Why Some of the Smartest People Can't Read and How They Can Learn. USA: A Perigee Book.

Eden, G. F., Jones, K. M., Cappell, K., Gareau, L., Wood, F. B., Zeffiro, T. A., Dietz, N. A. E., Agnew, J. A., \& Flowers, D. L. (2004). Neural Changes following Remediation in Adult Developmental Dyslexia. Neuron, 44, 411-422, October, 28, 2004. Available: https:// www.cell.com/action//showPdf?pii = 50896-6273\%2804\%2900675-0. Retrieved: 05.04.2020.

Engelhardt, P. E. (2020). Developmental Dyslexia: Where Do We Go from Here? Brain Sciences, 10, 151; doi: 10.3390/brainsci10030151.

Facoetti, A. (n.d.). Spatial Attention disorders in Developmental Dyslexia: Towards the prevention of Reading Acquisition Deficits. Available: http://www.decone.psy.unipd. it/Dc.Co.Ne_LAB_Unipd/A._Facoetti_files/1-VisualaspectofdyslexiachapterFacoetti.pdf. Retrieved: 25.01.2020. 
Facoetti, A., Paganoni, P., Turatto, M., Marzola, V., \& Masetti, G. G. (2000). Visualspatial Attention in Developmental Dyslexia. Cortex, 36, 109-123.

Facoetti, A., Trussardi, A. N., Ruffino, M., Lorusso, M. L., Cattaneo, C., Galli, R., Molteni, M., \& Zorzi M. (2009). Multisensory Spatial Attention Deficits Are Predictive of Phonological Decoding Skills in Developmental Dyslexia. doi:10.1162/ jocn.2009.21232.

Fletcher, J., \& Nicholas, K. (2016). Reading for 11-13 year-old students in the digital age: New Zealand case studies. http://doi.org/10.1080/03004279.2016.1170064.

Franceschini, S., Gori, S., Ruffino, M., Viola, S., Molteni, M., \& Facoetti, A. (2013). Action Video Games Make Dyslexic Children Read Better. http://dx.doi.org/10.1016/j. cub.2013.01.044.

Gaskins, I. W. (2005). Success with Struggling Readers: The Benchmark School Approach. New York/London: The Guilford Press.

Gibby-Leversuch, R., Hartwell, B. K., \& Wright, S. (2019). Dyslexia, Literacy Difficulties and the Self-Perceptions of Children and Young People: a Systematic Review. Current Psychology. https://doi.org/10.1007/s12144-019-00444-1.

Giles, Br. (2005a). Abnormal psychology. London: Grange Books.

Giles, Br. (2005b). Developmental Psychology. London: Grange Books.

Hubert-Gibon, G., Bru, M., Gras Le Guen, C., Launay, E., \& Roy, A. (2016). HealthRelated Quality of Life for Children and Adolescents with Specific Language Impairment: A Cohort Study by a Learning Disabilities Reference Center. Plos ONE. doi: 10.1371/ journal.pone.0166541.

Hudson, R. F., High, L., \& Al Otaiba, S. (2007). Dyslexia and the Brain: What Does Current Research Tell Us? Available: http://www.ldonline.org/article/14907/?theme=print Retrieved: 05.04.2020.

Jinot, B. L. (2019). An Evaluation of a Key Innovation: Mobile learning. Academic Journal of Interdisciplinary Studies, 8(2). doi: 10.2478/ajis-2019-0014.

Kossowski, B., Chyl, K., Kacprzak, A., Bogorodzki, P., \& Jednorog, K. (2019). Dyslexia and age related effects in the neurometabolites concentration in the visual and themporoparietal cortex. Scientific Reports, 9, 5096. https://doi.org/10.1038/s41598-019-41473-x.

Lavin-Mera, P., Torrente, J., Moreno-Ger, P., Vallejo-Pinto, J. A., \& Fernandez-Manjon, B. (2009). Mobile game Development for Multiple Devices in Education. iJET, 4(2), "IMCL2009". doi: 10.3991/ijrt.v4s2.910

McArthur, G., \& Castles, A. (2017). Helping children with reading difficulties: some things we have learned so far. Npj Science of Learning. Available: https://www.nature. com/npjscilearn. Retrieved: 20.02.2020.

Nielsen, K., Abbott, R., Griffin, W., Lott, J., Raskind, W., \& Berninger, V. W. (2016). Evidence-Based Reading and Writing Assessment for Dyslexia in Adolescents and Young Adults. Learn Disabil (Pittsbg), 21(1): 38-56. doi: 10.18666/LDMJ-2016-V21-11-6971.

Pechenkina, E., Laurence, D., Oates, G., Eldridge, D., \& Hunter, D. (2017). Using a gamified mobile app to increase student engagement, retention and academic achievement. International journal of Educational Technology in Higher Education. doi: 10.1186/s41239-017-0069-7.

Ramus, F., Marshall, C. R., Rosen, S., \& Van Der Lely, H. K. J. (2013). Phonological deficits in specific language impairment and developmental dyslexia: towards a multidimensional model. Brain, 136, 630-645. doi: 10.1093/brain/aws356. 
Ricketts, J., Lervag, A., Dawson, N., Taylor, L. A., \&Hulme, Ch. (2019). Reading and Oral Vocabulary Development in Early Adolescence. Scientific studies of Reading. doi: 10.1080/10888438.20191689244.

Snowling, M. J. (2015). Early identification and interventions for dyslexia: a contemporary view. J Res Spec Educ Needs. doi:10.1111/j.1471-3802.2012.01262.x.

Snowling. M., Muter, V., \& Carroll, J. (2007). Children at family risk of dyslexia: a followup in early adolescence. doi: 10.1111/j.1469-7610.2006.01725.x.

Stiller, K. D., \& Schworm, S. (2019). Game-Based Learning of the Structure and Functioning of Body Cells in a Foreign Language: Effects of Motivation, Cognitive Load, and Performance. Frontiers in Education, 4, 18. doi: 10.3389/feduc.2019.00018.

Thompson, P. A., Hulme, Ch., Nash, H. M., Gooch, D., Hayiou-Thomas, E., \& Snowling, M. J. (2015). Developmental dyslexia: predicting individual risk. The Journal of Child Psychology and Psychiatry. doi:10.1111/jcpp.12412.

Tubele, S. (2010). Interest in Reading - Facilitating Factor in Acquiring Reading Skills. In: Ad verba liberorum: Linguistics\& Pedagogy \& Psychology, 2(1), December 2010. Riga: Riga Teacher Training and Educational Management Academy, pp. 11-20 (ISSN 1691-5771).

Turkington, C., \& Harris, J (ed.) (2006). The Encyclopedia of Learning Disabilities. New York: American Bookworks.

Viser, T. A. V., Boden, C., \& Giaschi, D. E. (2004). Children with dyslexia: evidence for visual attention deficits in perception of rapid sequences of objects. Vision Research, 44, 2521-2535. doi: 10.1016/j.visres.2004.05.010.

Wardaszko, M., \& Podgorski, B. (2017). Mobile Learning Game Effectiveness in Cognitive Learning by Adults: A Comparative Study. https://doi.org/10.1177/1046878117704350. 